Supporting Information

\title{
Quinoxaline-based semiconducting polymer dots for in vivo NIR-II fluorescence imaging
}

Ye Liu ${ }^{\mathrm{a}}$, Jinfeng Liua, Dandan Chen ${ }^{\mathrm{b}}$, Xiaosha Wang ${ }^{\mathrm{a}}$, Zhenbao Liu ${ }^{\mathrm{c}}$, Hui Liu ${ }^{\mathrm{a}}$, Lihui Jiang $^{\mathrm{a}}$, Changfeng $\mathrm{Wu}^{\mathrm{b}}$, Yingping $\mathrm{Zou}^{\mathrm{a}, \mathrm{d} *}$

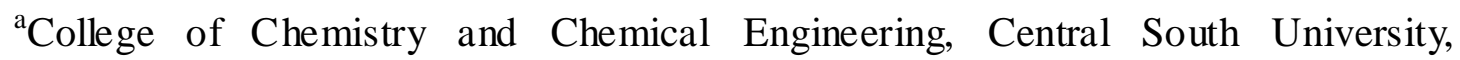
Changsha 410083, China. Email: yingpingzou@csu.edu.cn

${ }^{\mathrm{b}}$ Department of Biomedical Engineering, Southern University of Science and Technology, Shenzhen, Guangdong 518055, China.

${ }^{\mathrm{c}}$ Department of Pharmaceutics, Xiangya School of Pharmaceutical Sciences, Central South University, Changsha, 410013, China.

dMolecular Imaging Research Center of Central South University, Changsha 410008, Hunan, China

1. Supplementary Figures

2. Experimental section

3. Synthesis

4. ${ }^{1} \mathrm{H}$ NMR and ${ }^{13} \mathrm{C}$ NMR 


\section{Supplementary Figures}

a)

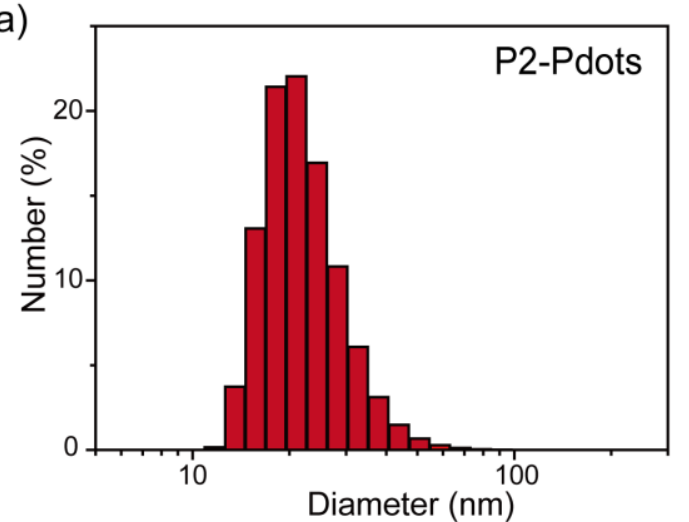

b)

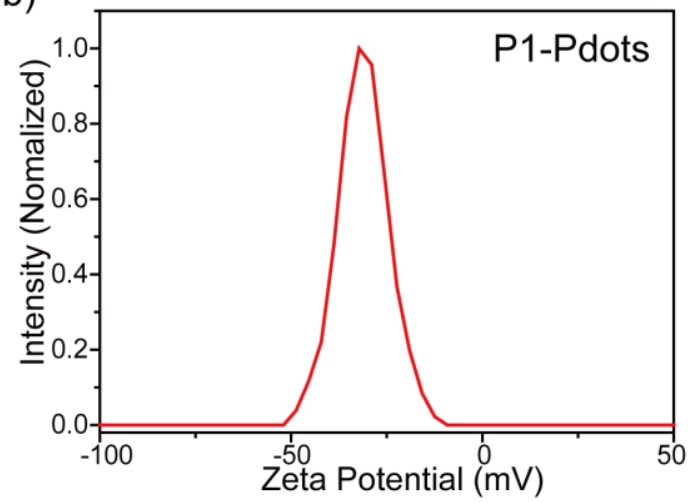

d)

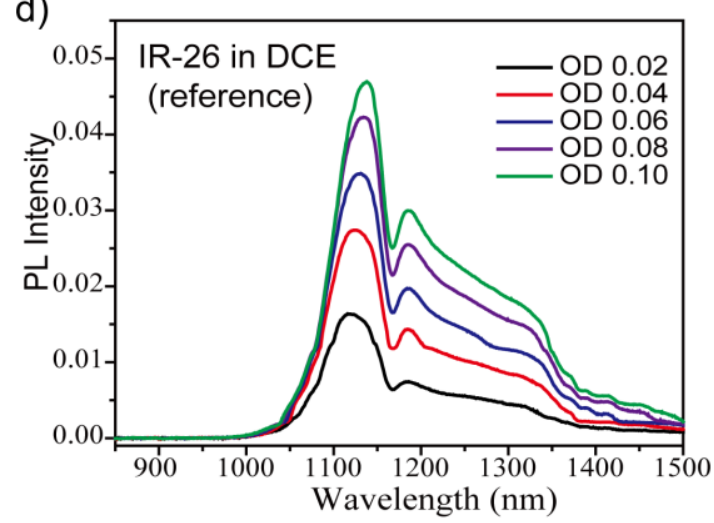

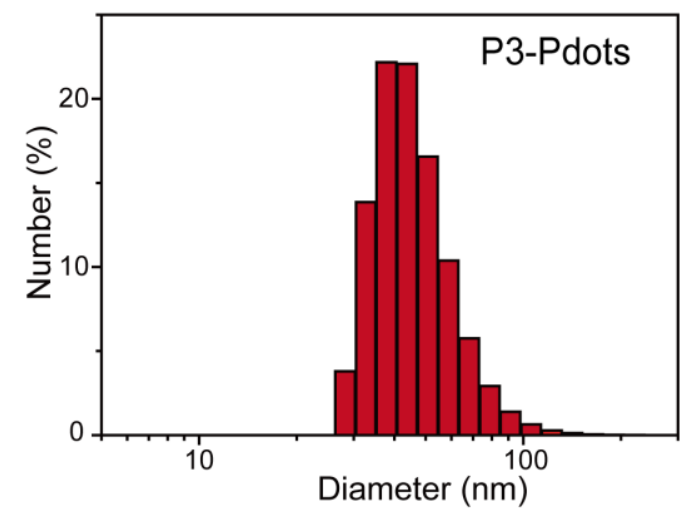

c)

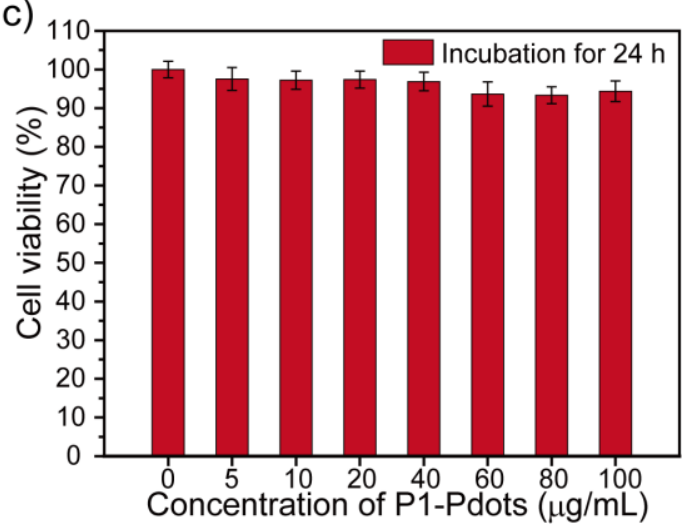

e)

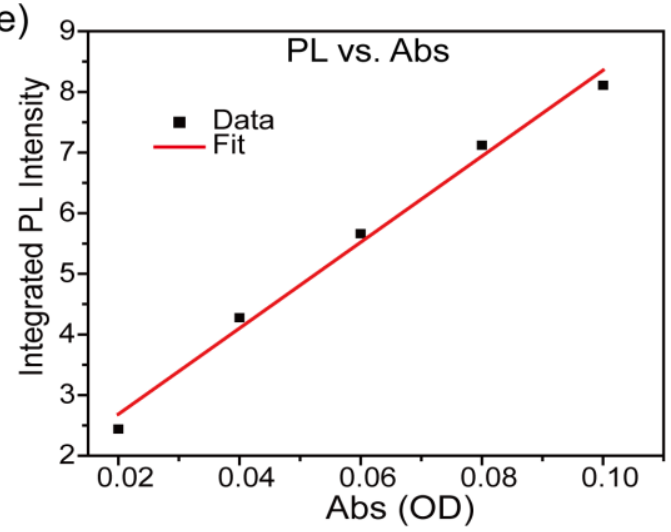

Fig. S1 (a) Size distribution histogram of P2-Pdots and P3-Pdots DLS. (b) Zeta potential of the P1-Pdots. (c) Cell viability of MCF-7 cells after incubation with P1-Pdots solution at various concentrations for $24 \mathrm{~h}$. (d) NIR-II emission spectra of the IR-26 reference solutions under an excitation of $808 \mathrm{~nm}$. (e) Integrated NIR-II fluorescence intensity plotted as a function of absorbance at $808 \mathrm{~nm}$ for IR-26 reference solutions. 


\section{Experimental section}

\section{Materials}

All materials were obtained from Sigma-Aldrich (St. Louis, MO, USA) and used without further purification unless otherwise indicated. Tetrakis(triphenylphosphine) palladium $\left(\mathrm{Pd}\left[\mathrm{PPh}_{3}\right]_{4}, 99 \%\right)$ was purchased from J\&K Chemical Ltd. (Beijing, China). (4,4,9,9-tetrakis(4-hexylphenyl)-4,9-dihydro-sind aceno[1,2-b :5,6-b']d ithiophene-2,7-d iyl)bis(trimethylstannane) was purchased from Derthon Optoelectronic Materials Science \& Technology Co., Ltd. (Shenzhen, China). Tetrahydrofuran (THF) was used to prepare the Pdots and was pretreated with sodium, followed by distillation. Ultrapure $\mathrm{H}_{2} \mathrm{O}\left(18.25 \mathrm{M} \Omega \cdot \mathrm{cm}^{-2}\right.$ at $\left.25^{\circ} \mathrm{C}\right)$ was used throughout the study, and all other chemical reagents were used as received.

\section{Characterization}

${ }^{1} \mathrm{H}$ NMR and ${ }^{13} \mathrm{C}$ NMR were recorded using a Bruker DMX-400 spectrometers with deuterated chloroform as solvent at $298 \mathrm{~K}$. Chemical shifts were reported as $\delta$ values (ppm) with tetramethylsilane (TMS) as the internal reference. Time-of-flight mass spectrometry (TOF-MS) was recorded with a Bruker Q-TOF Qualification Standard Kit. Ultraviolet (UV)-Vis-NIR absorption spectra were recorded on a Shimadzu UV-2600 spectrophotometer. PL spectra were measured with a Horiba iHR 320 fluorescence spectrophotometer. The molecular weight and polydispersity of the prepared polymers were measured by Gel Permeation Chromatography (GPC, 515HPLC pump, Waters, 2414 refractive index detector) in tetrahydrofuran (THF) 
using a calibration curve of polystyrene standards. The sizes and morphologies of the Pdots were investigated using transmission electron microscope (TEM, H-600; Hitachi, Japan) operating at an accelerating voltage of $100 \mathrm{kV}$. No staining was applied. The diameter distributions and zeta potential of the Pdots were determined by dynamic light scattering (DLS) with a Malvern Zeta sizer Nano ZS instrument. Methyl-thiazolyldiphenyl-tetrazolium (MTT) assays were performed using a microplate reader (BioTek Cytation 3, BioTek, Winooski, VT, USA).

\section{Preparation of semiconducting polymer dots (Pdots)}

Three conjugated polymers were successfully synthesized by Stille coupling polymerization reaction (Scheme 1 and Scheme S1, details see ESI). To prepare Pdots, conjugated polymer P1, or $\mathbf{P 2}$, or $\mathbf{P 3}$ was dissolved in anhydrous THF. THF solution containing P1, or P2, or P3 was mixed with PS-PEG-COOH with a 1:1 wt ratio and was quickly injected into ultrapure water under vigorous sonication and THF was then evaporated to obtain Pdots. These Pdots (named as P1-Pdots, P2-Pdots and P3-Pdots) were further filtered with a $0.22 \mu \mathrm{m}$ syringe filter to remove the large nanoparticles $^{[29,30]}$.

\section{Determination of fluorescence QY of P1-Pdots}

Fluorescence QY of P1-Pdots was measured according to the literature ${ }^{[31]}$, using the NIR-II fluorescent IR-26 dye $(\mathrm{QY}=0.5 \%)$ as the reference ${ }^{[32]}$. The IR-26 dye was diluted with 1,2-dichloroethane (DCE) solution to different absorbance value $(0.10$, $0.08,0.06,0.04$ and 0.02 ) at $808 \mathrm{~nm}$. Then, the fluorescence emission spectrum of these solutions were measured under an 808-nm diode laser (Fig. S1d). The 
absorption and emission of P1-Pdots were measured in aqueous solution similarly (Fig. 2c). The integrated NIR-II fluorescence intensity was plotted against absorbance at the excitation wavelength of $808 \mathrm{~nm}$ and fitted into a linear function. Two slopes, one obtained from the reference of IR-26 (Fig. S1e) in DCE and the other from the P1-Pdtos (Fig. 2d), were based on equation as follows:

$$
Q Y_{\text {sample }}=Q Y_{\text {ref }} \times \frac{\text { slope }_{\text {sample }}}{\text { slope }_{\text {ref }}} \times\left(\frac{n_{\text {sample }}}{n_{\text {ref }}}\right)^{2}
$$

$n_{\text {sample }}$ and $n_{\text {ref }}$ are the refractive indices of water and DCE, respectively.

\section{Cytotoxicity of P1-Pdots}

MCF-7 breast cancer cells were cultured at $37^{\circ} \mathrm{C}$ in Dulbecco's Modified Eagle Medium (DMEM) containing 10\% fetal bovine serum and 1\% penicillin/streptomycin in a humidified environment with $5 \% \mathrm{CO}_{2}$ and $95 \%$ air. The activities of MCF-7 cells in vitro were evaluated using MTT assays. MCF-7 were seeded in 96-well cell culture plates (Costar Chicago, IL, USA) at an intensity of $5 \times 10^{3}$ cells per well. After $24 \mathrm{~h}$ incubation, the medium was replaced with fresh medium containing P1-Pdots at different concentrations $\left(0-100 \mu \mathrm{g} \mathrm{mL} L^{-1}\right)$, and the MCF-7 cells were then incubated for $24 \mathrm{~h}$. Subsequently, MTT (20 $\mu \mathrm{L}, 5 \mathrm{mg} \mathrm{mL}^{-1}$ ) was added to each well, and the cells were incubated for $4 \mathrm{~h}$. Then, the medium containing P1-Pdots and MTT was replaced with dimethyl sulfoxide $(150 \mu \mathrm{L}$ per well). After shaken for $10 \mathrm{~min}$ at room temperature, the absorbance value of each well was measured at $490 \mathrm{~nm}$ using microplate reader (Bio Tek Cytation 3). The cell viability was calculated using the ratio of the absorbance of the cells incubated with P1-Pdots to that of the cells incubated with culture medium only. 


\section{In vivo subcutaneous tumor imaging}

All experiments involving animals were carried out in according with the Guidelines stipulated by the Animal Care and Use Committee (IACUC), Southern University of Science and Technology. Female BALB/c nude mice were obtained from Vital River Laboratory Animal Technology Co., Ltd. (Beijing, China) and used at six-week-old. The MCF-7 tumor model was established by subcutaneous injection of MCF-7 $\left(2 \times 10^{7}\right.$ cells in $100 \mu \mathrm{L}$ PBS $)$ cells into the right shoulder of female nude mice. After tumors were grown for approximately two weeks, the nude mice $(n=3)$

were injected with $100 \mu \mathrm{L}$ of P1-Pdots $\left(200 \mu \mathrm{g} \mathrm{mL}^{-1}\right)$ through the tail vein for the imaging study. NIR-II fluorescence imaging was performed using a Series III 900/1700 whole animal imaging system (NIR OPTICS, Suzhou, China). Fluorescence images of the mice were acquired at designated time points (0-24 h) after P1-Pdots has been injected. The ex vivo biodistribution studies were further performed after 24 h post-injection of the nanoprobe to evaluate the distribution of P1-Pdots in tumor and major organs.

\section{Synthesis}



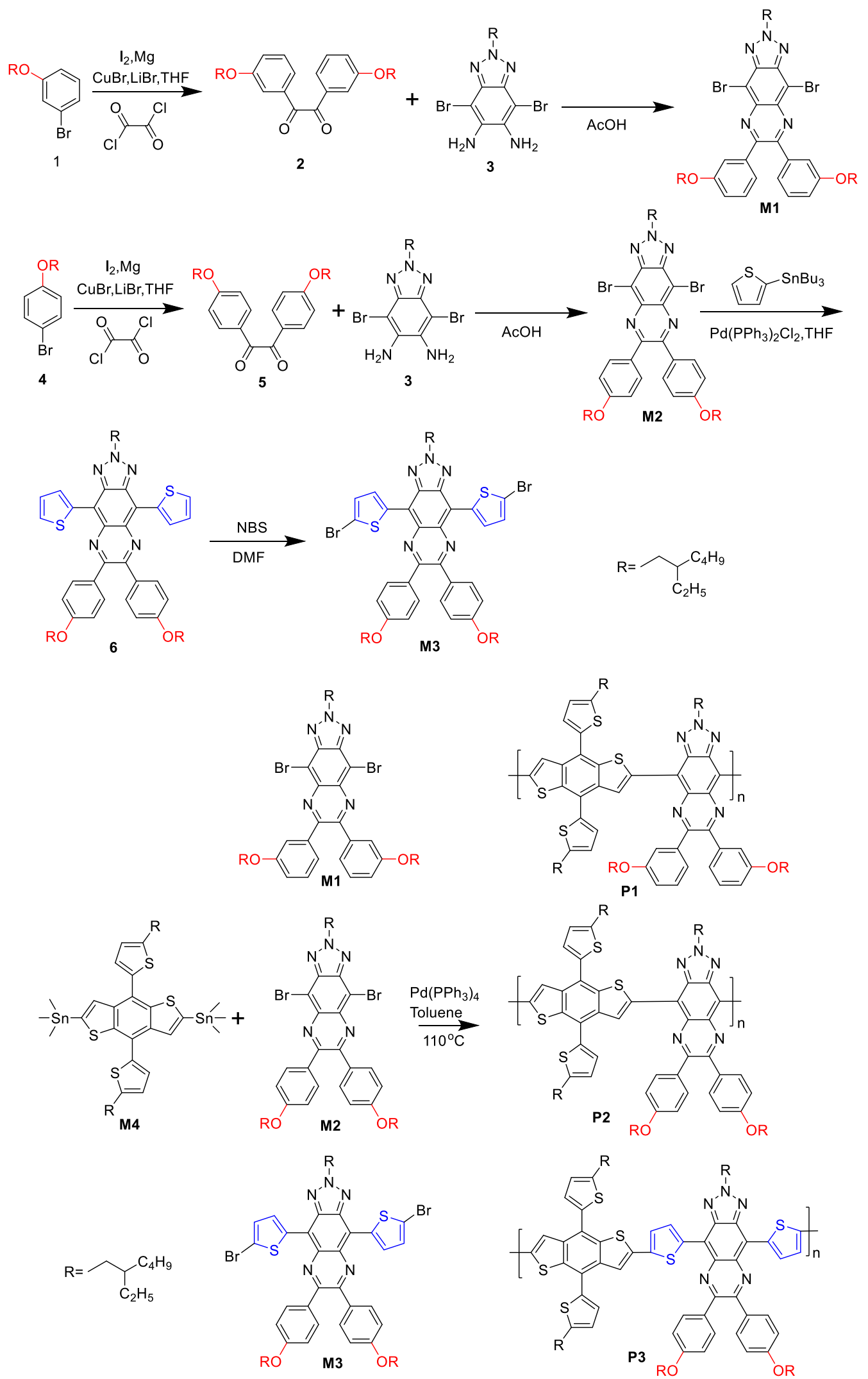

Scheme S1 Synthetic route and chemical structure of polymer. 


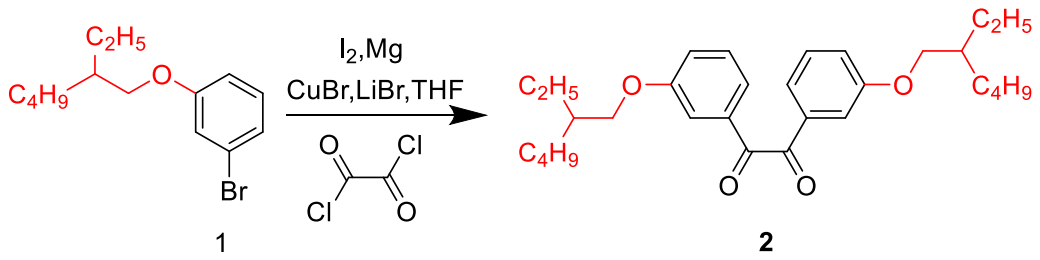

Under vigorous stirring, 1-bromo-3-((2-ethylhexyl)oxy)benzene (1) (9.15 g, 32.22 mmol) was added dropwisely to $\mathrm{Mg}$ turnings (0.97 $\mathrm{g}, 40.69 \mathrm{mmol})$ in anhydrous THF $(60 \mathrm{~mL})$ which was protected by Ar. During the process, $\mathrm{I}_{2}(12 \mathrm{mg})$ was added as catalyst in the reaction. The solution was refluxed for $6 \mathrm{~h}$ until the $\mathrm{Mg}$ was consumed. The mixture was refluxed for one more hour and then was cooled down. The solution system was added slowly to $\mathrm{LiBr}(5.6 \mathrm{~g}, 64.44 \mathrm{mmol})$ and $\mathrm{CuBr}(4.64 \mathrm{~g}, 32.22 \mathrm{mmol})$ dispersed in $60 \mathrm{~mL}$ THF under $0^{\circ} \mathrm{C}$. $(\mathrm{CO})_{2} \mathrm{Cl}_{2}(1.92 \mathrm{~g}, 15.11 \mathrm{mmol})$ was added dropwisely into the above reaction mixture and continued to stir for $30 \mathrm{~min}$. The solution was stirred for another $2 \mathrm{~h}$ at room temperature, then the mixture was poured into water and extracted with dichloromethane (DCM), the organic extraction was washed successively with water and $\mathrm{NaHCO}_{3}$ solution twice and the combined organic phase was dried over $\mathrm{MgSO}_{4}$ and evaporated to afford the crude product. The crude product was purified on a silica gel column, eluting with pure hexane. Light yellow viscous liquid were obtained (2.38 g, $15.8 \%$ yield). ${ }^{1} \mathrm{H}$ NMR (400 MHz, $\left.\mathrm{CDCl}_{3}\right) \delta 7.56(\mathrm{~s}, 2 \mathrm{H}), 7.46-7.44(\mathrm{~d}, J=8 \mathrm{~Hz}, 2 \mathrm{H}), 7.40-7.36(\mathrm{t}, J=16 \mathrm{~Hz}, 2 \mathrm{H})$, 7.23-7.21 (q, $J=8 \mathrm{~Hz}, 2 \mathrm{H}), 3.91-3.89$, (d, $J=8 \mathrm{~Hz}, 4 \mathrm{H}), 1.76-1.70(\mathrm{~m}, 2 \mathrm{H}), 1.53-1.31$ (m, $16 \mathrm{H}), 0.95-0.89(m, 12 \mathrm{H}) . \mathrm{MS}: \mathrm{m} / \mathrm{z}$ calc. for $\mathrm{C}_{30} \mathrm{H}_{42} \mathrm{O}_{4} 466.31$; found 466.85 .

\section{2.}

4,9-dibromo-2-(2-ethylhexyl)-6,7-bis(3-((2-ethylhexyl)oxy)phenyl)-2H-[1,2,3]triazol o[4,5-g]quinoxaline (M1) 


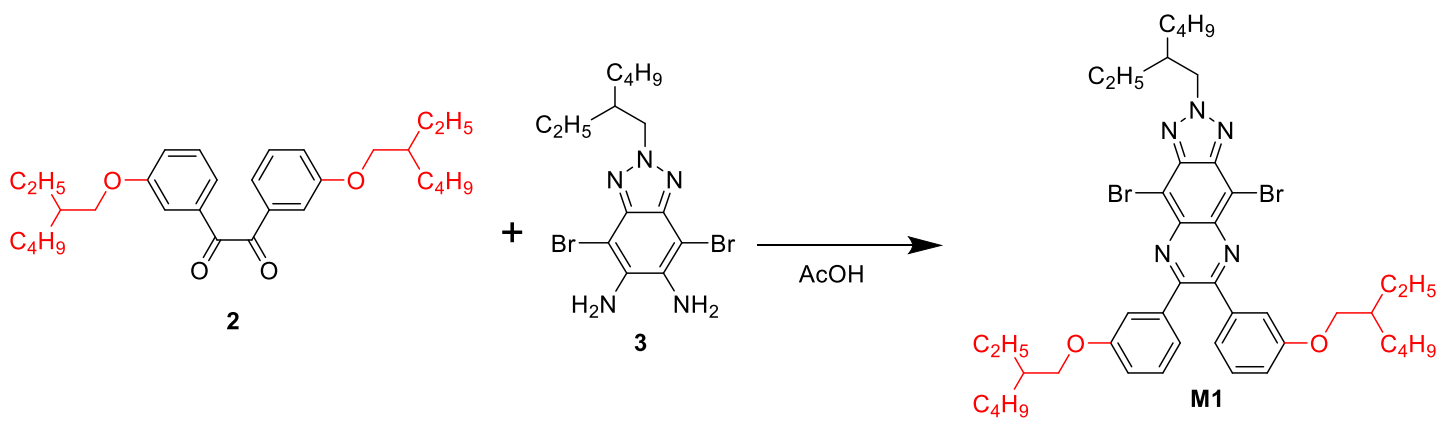

1,2-bis(3-((2-ethylhexyl)oxy)phenyl)ethane-1,2-dione (2) (2.38 g, $5.11 \mathrm{mmol})$ was suspended in $80 \mathrm{~mL} \mathrm{AcOH}$ and compound (3) (2.57 g, $6.13 \mathrm{mmol})$ dissolved in 60 $\mathrm{mL} \mathrm{AcOH}$ was added. The suspension was heated to $60{ }^{\circ} \mathrm{C}$ for $1 \mathrm{~h}$ and then the temperature was raised to $120{ }^{\circ} \mathrm{C}$ for $3 \mathrm{~h}$. The solution was stirred over night at $90^{\circ} \mathrm{C}$. After cooling to room temperature, the mixture was poured into water and extracted with DCM, the organic extraction was washed successively with water and $\mathrm{NaHCO}_{3}$ solution twice, the combined organic phase was dried over $\mathrm{MgSO}_{4}$ and evaporated to afford the crude product. The crude product was purified on a silica gel column, eluting with $\mathrm{DCM} / \mathrm{hexane}=1 / 7$. Yellow viscous liquid were obtained $(2.94 \mathrm{~g}, 68 \%$ yield). ${ }^{1} \mathrm{H}$ NMR (500 MHz, $\left.\mathrm{CDCl}_{3}\right) \delta 7.28(\mathrm{~s}, 2 \mathrm{H}), 7.27-7.26(\mathrm{~d}, J=4 \mathrm{~Hz}, 2 \mathrm{H})$, 7.25-7.24 (d, $J=4 \mathrm{~Hz}, 2 \mathrm{H}), 6.98-6.95(\mathrm{~d}, J=12 \mathrm{~Hz}, 2 \mathrm{H}), 4.85-4.83(\mathrm{~d}, J=8 \mathrm{~Hz}, 2 \mathrm{H})$, 3.74-3.72 (d, J=8 Hz, 4H), 2.46-2.43 (m, 1H), 1.72-1.66 (m, 2H), 1.52-1.32 (m, 24H), 0.99-0.86 (m, 18H). ${ }^{13} \mathrm{C}$ NMR (101 MHz, $\left.\mathrm{CDCl}_{3}\right) \delta 158.17,153.17,143.09,138.19$, $135.33,128.22,121.45,115.87,114.70,109.47,69.61,60.80,39.48,38.19,29.48$, $29.37,29.19,28.67,28.02,27.23,22.90,22.82,22.05,21.80,13.07,12.90,10.04$, 9.38. MS: $\mathrm{m} / \mathrm{z}$ calc. for $\mathrm{C}_{44} \mathrm{H}_{59} \mathrm{Br}_{2} \mathrm{~N}_{5} \mathrm{O}_{2}$ 847.30; found 848.13. 


\section{1,2-bis(4-((2-ethylhexyl)oxy)phenyl)ethane-1,2-dione (5)}

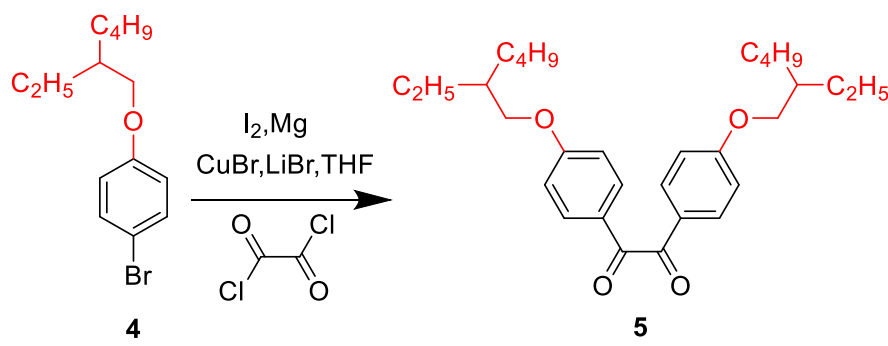

5 was synthesized according to the synthetic method of 2 . Light yellow viscous liquid were obtained (2.63 g, 17.5\% yield). ${ }^{1} \mathrm{H}$ NMR (400 MHz, $\left.\mathrm{CDCl}_{3}\right) \delta$ 7.86-7.84 (d, $J=8 \mathrm{~Hz}, 4 \mathrm{H}), 6.89-6.87$ (d, $J=8 \mathrm{~Hz}, 4 \mathrm{H}), 3.85-3.84$, (d, $J=4 \mathrm{~Hz}, 4 \mathrm{H}), 1.69-1.64$ (m, $2 \mathrm{H}), 1.43-1.23(\mathrm{~m}, 16 \mathrm{H}), 0.87-0.81(m, 12 \mathrm{H})$. MS: $\mathrm{m} / \mathrm{z}$ calc. for $\mathrm{C}_{16} \mathrm{H}_{22} \mathrm{Br}_{2} \mathrm{~N}_{2} \mathrm{O}_{2}$ 434.17; found 434.735. MS: $\mathrm{m} / \mathrm{z}$ calc. for $\mathrm{C}_{30} \mathrm{H}_{42} \mathrm{O}_{4} 466.31$; found 466.77 .

4.

4,9-dibromo-2-(2-ethylhexyl)-6,7-bis(4-((2-ethylhexyl)oxy)phenyl)-2H-[1,2,3]triazol o[4,5-g]quinoxaline (M2)
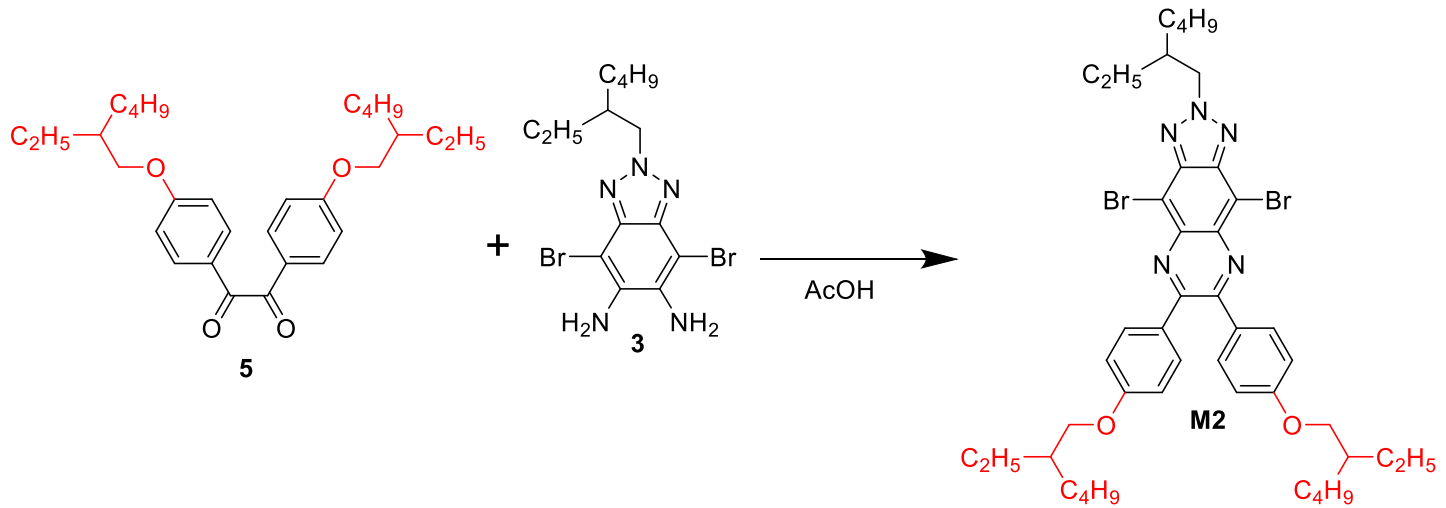

M2 was synthesized according to the synthetic method of M1. Light yellow viscous liquid were obtained (3.11 g, 72\% yield). ${ }^{1} \mathrm{H}$ NMR (400 $\left.\mathrm{MHz}, \mathrm{CDCl}_{3}\right) \delta$ 7.72-7.70 (d, $J=8 \mathrm{~Hz}, 4 \mathrm{H}), 6.92-6.90(\mathrm{~d}, J=8 \mathrm{~Hz}, 4 \mathrm{H}), 4.83-4.82(\mathrm{~d}, J=4 \mathrm{~Hz}, 2 \mathrm{H})$, 3.90-3.89 (d, J=4 Hz, 4H), 2.46-2.43 (m, 1H), 1.78-1.72 (m, 2H), 1.56-1.25 (m, 24H), 0.98-0.85 (m, 18H). $\left.{ }^{13} \mathrm{C} \mathrm{NMR} \mathrm{(101} \mathrm{MHz,} \mathrm{CDCl}_{3}\right) \delta 159.88,152.64,142.75,135.17$, $130.73,129.44,127.76,113.25,108.72,69.54,64.44,60.58,39.35,38.30,29.48$, 
29.29, 28.06, 27.20, 25.88, 22.82, 22.01, 21.80, 18.16, 13.07, 12.92, 10.10, 9.34. MS: $\mathrm{m} / \mathrm{z}$ calc. for $\mathrm{C}_{44} \mathrm{H}_{59} \mathrm{Br}_{2} \mathrm{~N}_{5} \mathrm{O}_{2} 847.30$; found 848.07.

5.

2-(2-ethylhexyl)-6,7-bis(4-((2-ethylhexyl)oxy)phenyl)-4,9-di(thiophen-2-yl)-2H-[1,2, 3]triazolo[4,5-g]quinoxaline (6)
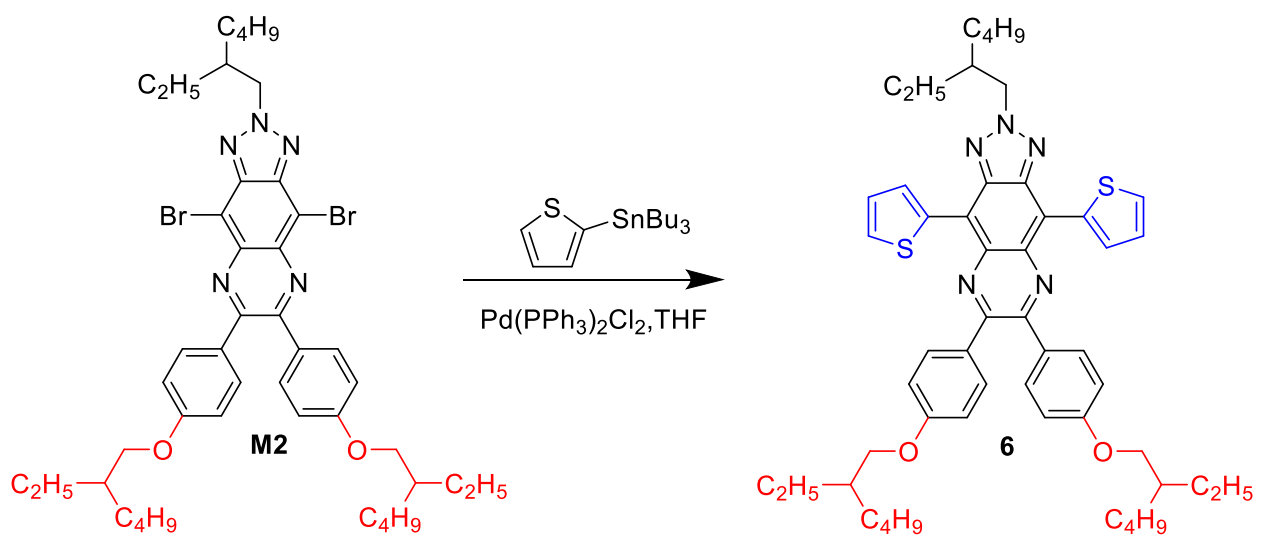

To a solution of compound M2 (0.56 g, $0.67 \mathrm{mmol})$, tributyl(thiophene-2-yl)stannane (0.55 g, $1.48 \mathrm{mmol})$ and $\mathrm{PdCl}_{2}\left(\mathrm{PPh}_{3}\right)_{2}(0.019 \mathrm{~g}, 0.023 \mathrm{mmol})$ in THF (20 ml) and the reaction mixture was heated to reflux for $48 \mathrm{~h}$ under an argon atmosphere. The mixture was cool to room temperature and then concentrated under reduced pressure. The crude product was chromatographically purified on a silica gel column eluting with DCM/hexane (1:9, v/v) to afford compound 6 as an black blue solid (0.45 g, 78.00 \% yield). ${ }^{1} \mathrm{H}$ NMR (400 MHz, $\left.\mathrm{CDCl}_{3}\right) \delta$ 7.95-7.94 (d, J=4 Hz, 2H), 7.85-7.84 (d, $J=4 \mathrm{~Hz}, 2 \mathrm{H}), 7.70-7.68$ (d, $J=8 \mathrm{~Hz}, 4 \mathrm{H}), 6.93-6.91$ (d, $J=8 \mathrm{~Hz}, 4 \mathrm{H}), 6.73-6.71$ (q, $J=8 \mathrm{~Hz}, 2 \mathrm{H}), 4.92-4.91$ (d, $J=4 \mathrm{~Hz}, 2 \mathrm{H}), 3.90-3.89$ (d, $J=4 \mathrm{~Hz}, 4 \mathrm{H}), 2.47-2.44(\mathrm{~m}, 1 \mathrm{H})$, 1.78-1.72 (m, 2H), 1.62-1.29 (m, 24H), 1.01-0.86 (m, 18H). MS: m/z calc. for $\mathrm{C}_{52} \mathrm{H}_{65} \mathrm{~N}_{5} \mathrm{O}_{2} \mathrm{~S}_{2}$ 855.46; found 856.21.

6.

4,9-bis(5-bromothiophen-2-yl)-2-(2-ethylhexyl)-6,7-bis(4-((2-ethylhexyl)oxy)phenyl) -2H-[1,2,3]triazolo[4,5-g]quinoxaline (M3) 


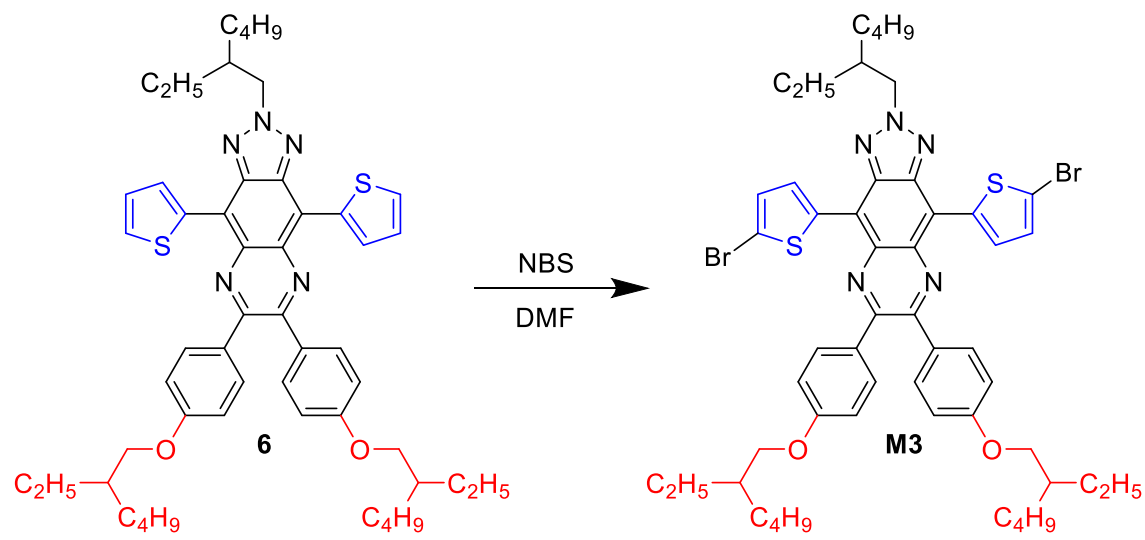

To a solution of compound $6(0.77 \mathrm{~g}, 0.90 \mathrm{mmol})$ in DMF $(20 \mathrm{~mL})$ was added $N$-bromosuccinimide (NBS) (0.353 g, $1.98 \mathrm{mmol})$ in portions under $40 \mathrm{mins}$. The mixture was stirred at room temperature in the dark for $24 \mathrm{~h}$. The solution was concentrated in vacuum and the residue was chromatographically purified on a silica gel column eluting with DCM/hexane (1:8, v/v) to afford M3 as a black blue solid (0.65 g, 71.23\% yield). ${ }^{1} \mathrm{H}$ NMR (400 MHz, $\left.\mathrm{CDCl}_{3}\right) \delta 8.70-8.69(\mathrm{~d}, J=4 \mathrm{~Hz}, 2 \mathrm{H})$, 7.72-7.70 (d, J=8 Hz, 4H), 7.20-7.19 (d, J=4 Hz, 2H), 6.97-6.95 (d, J=8 Hz, 4H), 4.82-4.90 (d, $J=8 \mathrm{~Hz}, 2 \mathrm{H}), 3.94-3.83$ (d, $J=4 \mathrm{~Hz}, 4 \mathrm{H}$ ), 2.35-2.30 (m, 1H), 1.81-1.75 $(\mathrm{m}, 2 \mathrm{H}), 1.56-1.31(\mathrm{~m}, 24 \mathrm{H}), 1.02-0.88(\mathrm{~m}, 18 \mathrm{H}) .{ }^{13} \mathrm{C} \mathrm{NMR}\left(101 \mathrm{MHz}, \mathrm{CDCl}_{3}\right) \delta$ $160.44,151.36,140.90,137.35,132.52,132.25,131.50,130.57,129.15,118.97$, 117.82, 114.05, 70.70, 60.17, 40.26, 39.61, 31.54, 30.71, 30.66, 30.31, 29.81, 29.29, $28.35,24.11,24.04,23.21,23.06,14.27,14.18,11.34,10.52,1.16 . \mathrm{MS}: \mathrm{m} / \mathrm{z}$ calc. for $\mathrm{C}_{44} \mathrm{H}_{59} \mathrm{Br}_{2} \mathrm{~N}_{5} \mathrm{O}_{2}$ 847.30; found 848.13. MS: m/z calc. for $\mathrm{C}_{52} \mathrm{H}_{65} \mathrm{Br}_{2} \mathrm{~N}_{5} \mathrm{O}_{2} \mathrm{~S}_{2}$ 1011.28; found 1012.52 .

7.

Poly([4,4,9,9-tetrakis(4-hexylphenyl)-4,9-dihydro-sindaceno[1,2-b:5,6-b']

dithiophene-2,7-diyl]-co-[6-(2-ethylhexyl)-[1,2,5]thiadiazolo[3,4-f]benzotriazole-4,8

-diyl]) (P1) 


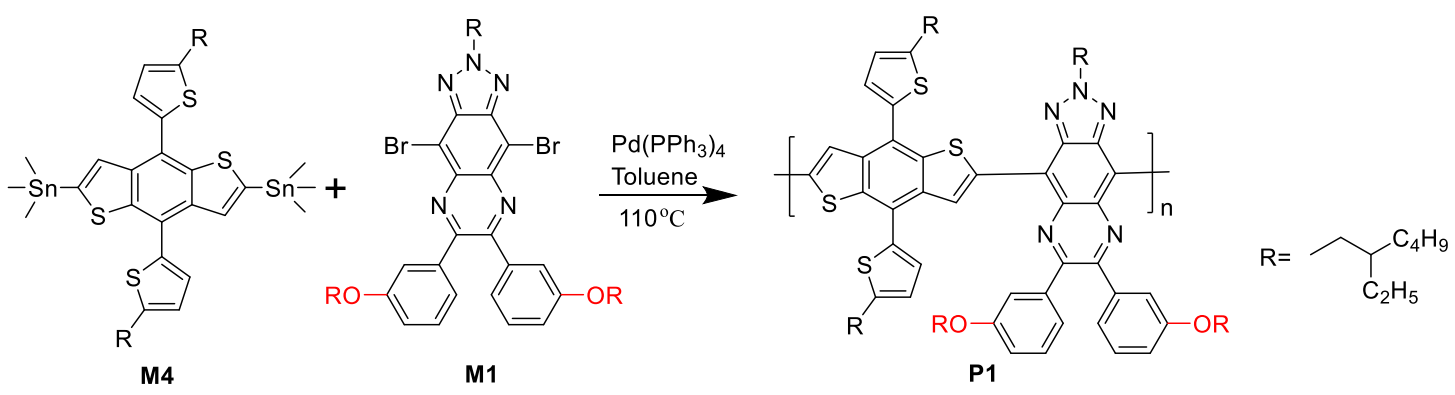

Stille coupling polymerization reaction is the palladium-catalysed cross coupling used to synthesize the copolymers as shown in Scheme S1. In a $25 \mathrm{~mL}$ three-necked flask, monomer M1 (169 mg, $0.2 \mathrm{mmol})$ and monomer M4 (181 mg, $0.2 \mathrm{mmol})$, were dissolved in toluene $(10 \mathrm{~mL})$. The reactant mixture was stirred at room temperature and then the flask was degassed and recharged with argon (repeated 3 times) to remove air before and after addition the catalyst $\mathrm{Pd}\left(\mathrm{PPh}_{3}\right)_{4}(5 \mathrm{mg}, 0.004 \mathrm{mmol})$. The mixture solution was stirred at $110^{\circ} \mathrm{C}$ for 2 days under nitrogen atmosphere and then 1 $\mathrm{mL}$ of (4,4,5,5-tetramethyl-1,3,2-dioxaborolan-2-yl)benzene $(20 \mathrm{mg}$, dissolved in toluene) and $0.2 \mathrm{~mL}$ of bromobenzene were gradually added dropwise to reactants to remove the end groups separately. Once the hot solution reached ambient temperature, the solution was washed with ultrapure water and purifed through Soxhlet extraction. After which it was recrystallized (methanol), and evaporated (vacuum). Product: black green solid, yield: $169 \mathrm{mg}, 66.74 \%$. Molecular weight of polymer was measured by $\mathrm{GPC}$ as $M \mathrm{n}=25.8 \mathrm{kDa}, M \mathrm{w}=40.9 \mathrm{kDa}$, polydispersity index $(\mathrm{PDI})=1.58$.

8.

Poly([2,5-bis(2-decyltetradecyl)-2,5-dihydropyrrolo[3,4-c]pyrrole-1,4-dione-3,6-dithi enyl]-co-[6-(2-ethylhexyl)-[1,2,5]thiadiazolo[3,4-f]benzotriazole-4,8-diyl]) (P2) 


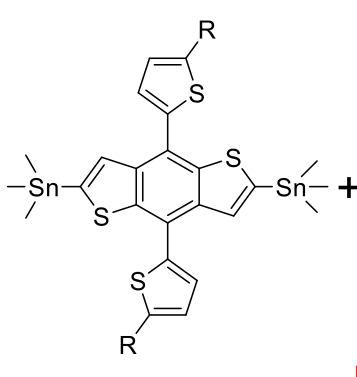

M4

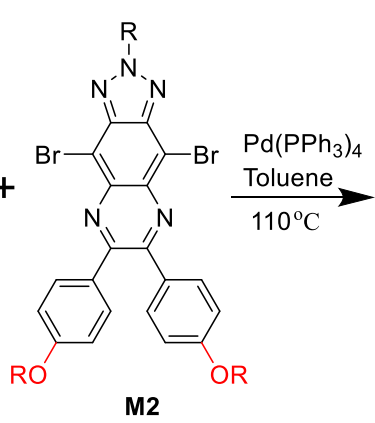

M2

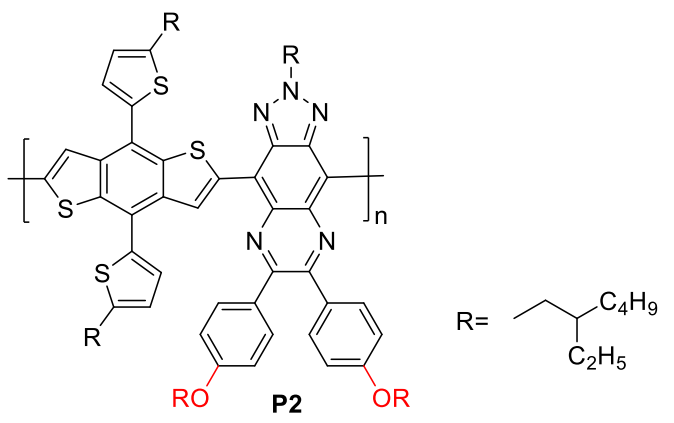

P2

P2 was synthesized according to the synthetic method of P1. Reactants: monomer M2 (169 mg, $0.2 \mathrm{mmol}$ ) and monomer M4 (181 mg, $0.2 \mathrm{mmol})$; Product: black green solid, yield: $173 \mathrm{mg}, 68.32 \%$. Molecular weight was measured by GPC as $M \mathrm{n}=24.2$ $\mathrm{kDa}, M \mathrm{w}=40.1 \mathrm{kDa}, \mathrm{PDI}=1.65$.

\section{9.}

Poly([4,8-bis(5-(2-ethylhexyl)thiophen-2-yl)benzo[1,2-b:4,5-b ']dithiophene-2,6-diyl] -co-[6-(2-ethylhexyl)-[1,2,5]thiadiazolo[3,4-f]benzotriazole-4,8-diyl]) (P3)

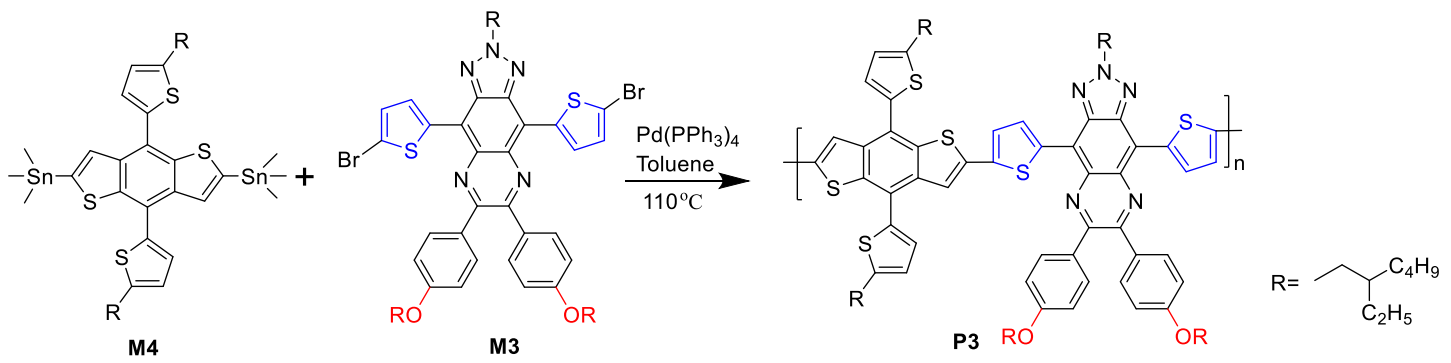

P3 was synthesized according to the synthetic method of P1. Reactants: monomer M3 (202 mg, $0.2 \mathrm{mmol}$ ) and monomer M4 (181 mg, $0.2 \mathrm{mmol})$; Product: black green solid, yield: $186 \mathrm{mg}, 65.08 \%$. Molecular weight was measured by GPC as $\mathrm{Mn}=21.9$ $\mathrm{kDa}, M \mathrm{w}=51.2 \mathrm{kDa}$, PDI $=2.33$. 


\section{4. ${ }^{1}$ H NMR and ${ }^{13}$ C NMR}

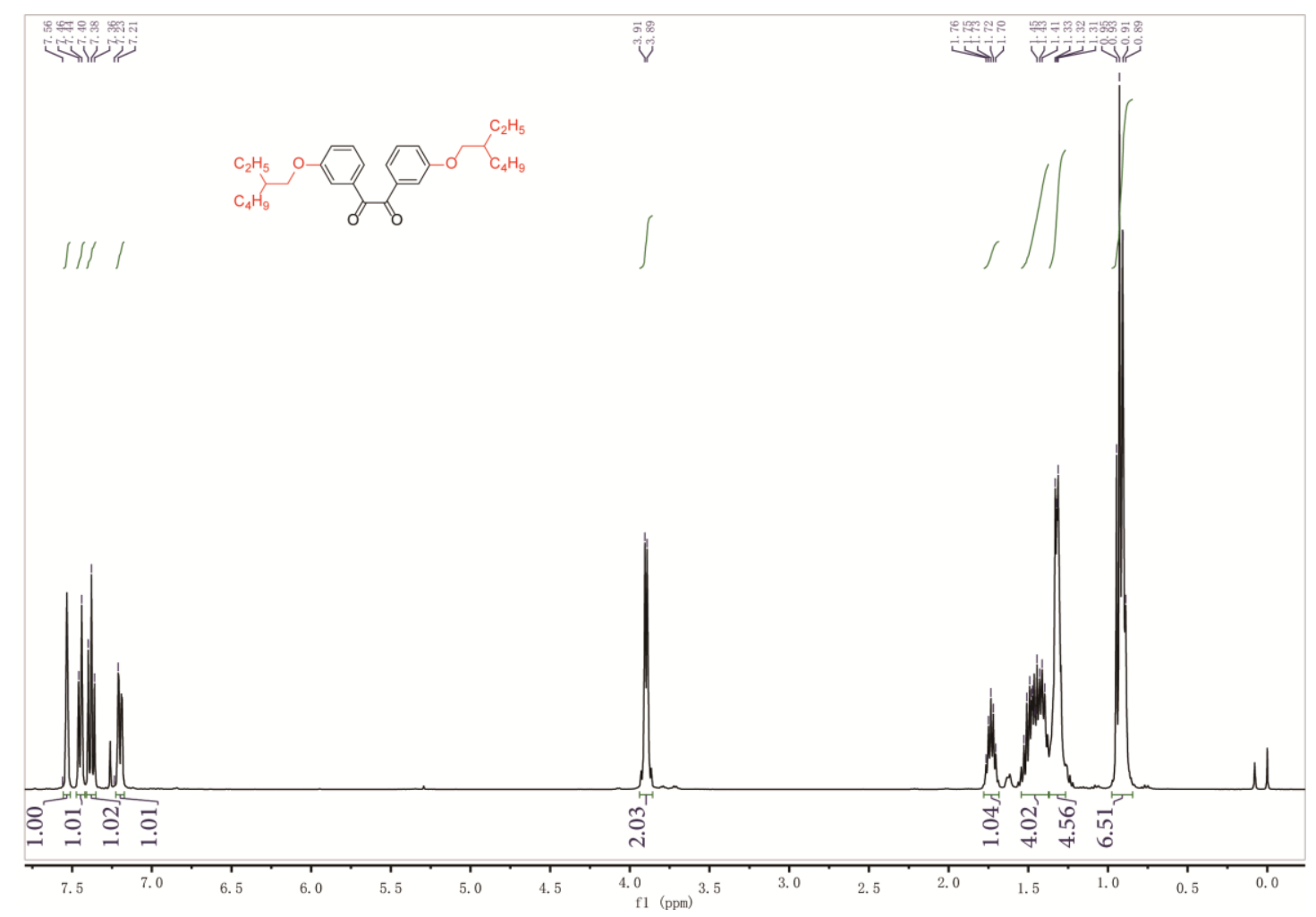

Fig. S2 ${ }^{1}$ H NMR spectrum of 1,2-bis(3-((2-ethylhexyl)oxy)phenyl)ethane-1,2-dione (2) 


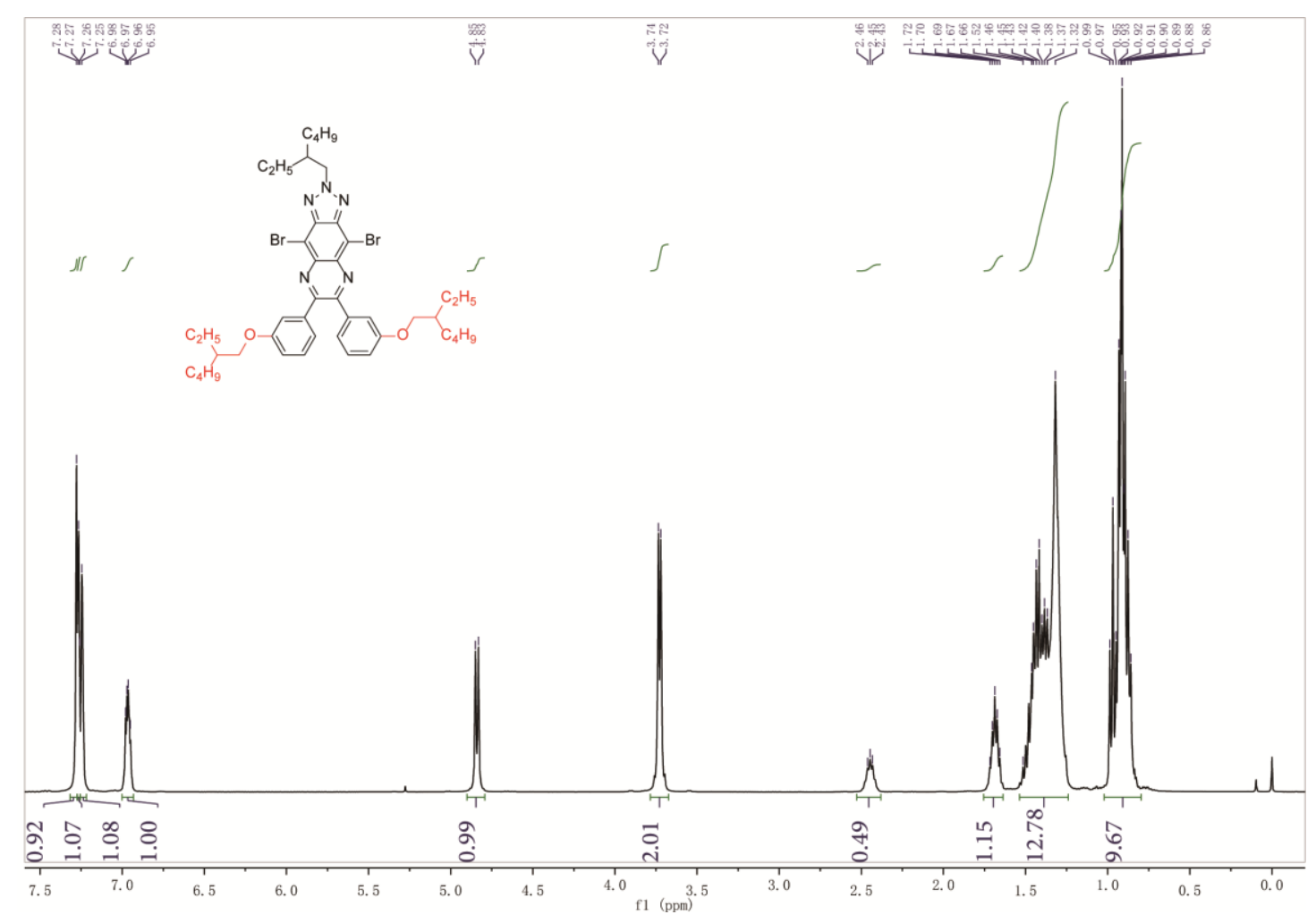

Fig. $\mathbf{S 3}{ }^{1} \mathrm{H}$ NMR spectrum of

4,9-dibromo-2-(2-ethylhexyl)-6,7-bis(3-((2-ethylhexyl)oxy)phenyl)-2H-[1,2,3]triazolo[4,5-g]quin oxaline (M1) 


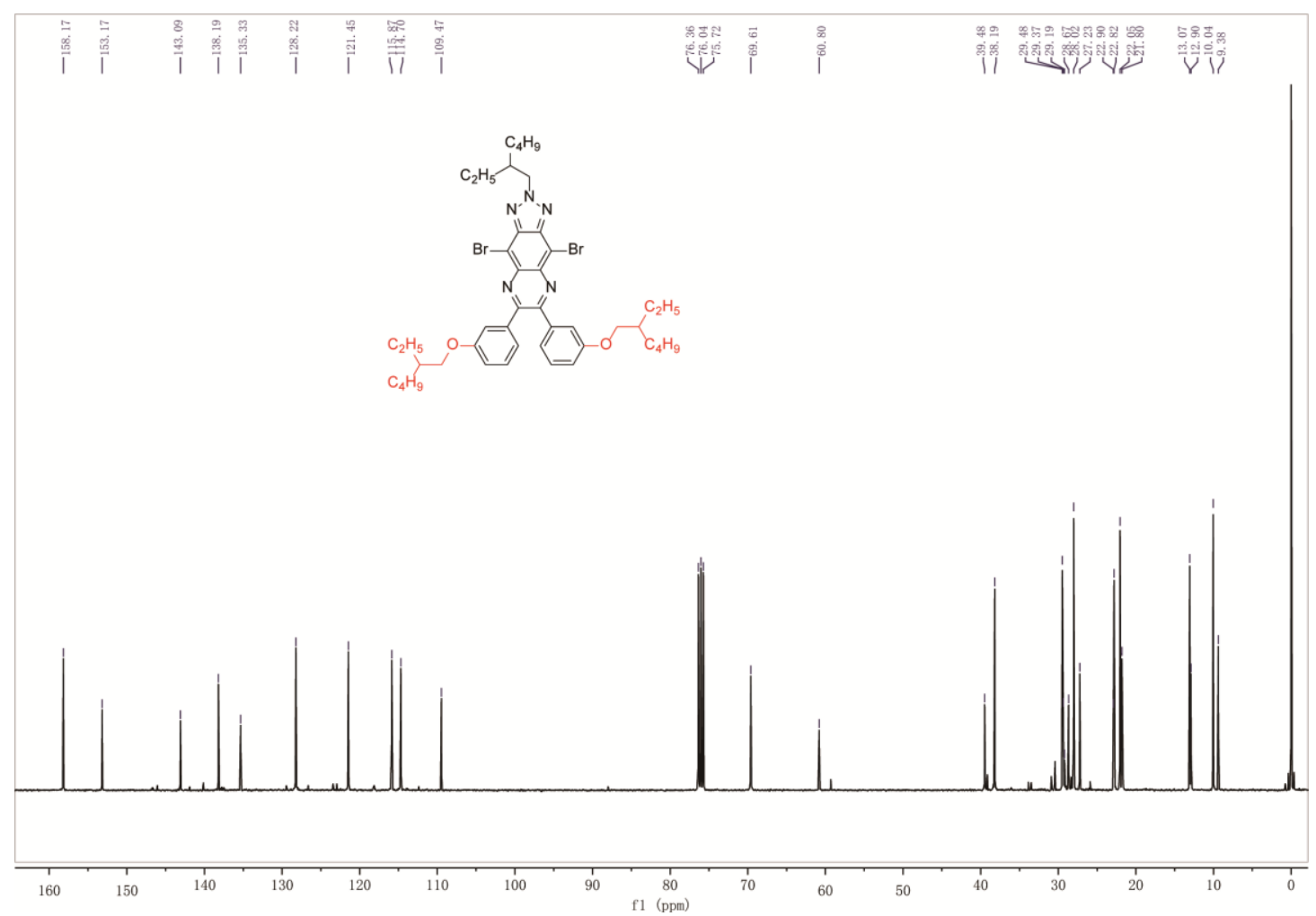

Fig. $\mathbf{S 4}{ }^{13} \mathrm{C}$ NMR spectrum of

4,9-dibromo-2-(2-ethylhexyl)-6,7-bis(3-((2-ethylhexyl)oxy)phenyl)-2H-[1,2,3]triazolo[4,5-g]quin oxaline (M1)

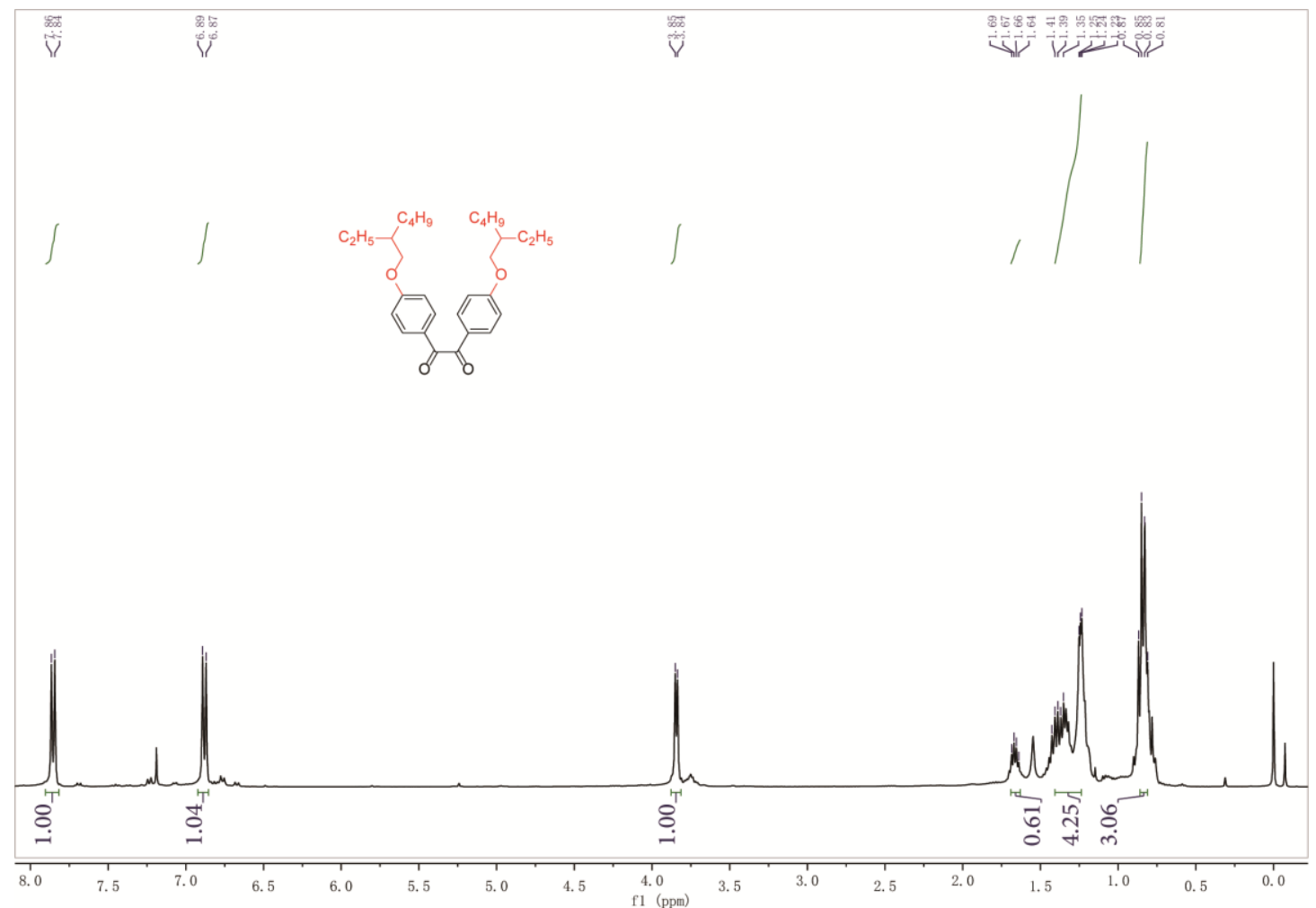

Fig. S5 ${ }^{1}$ H NMR spectrum of 1,2-bis(4-((2-ethylhexyl)oxy)phenyl)ethane-1,2-dione (5) 


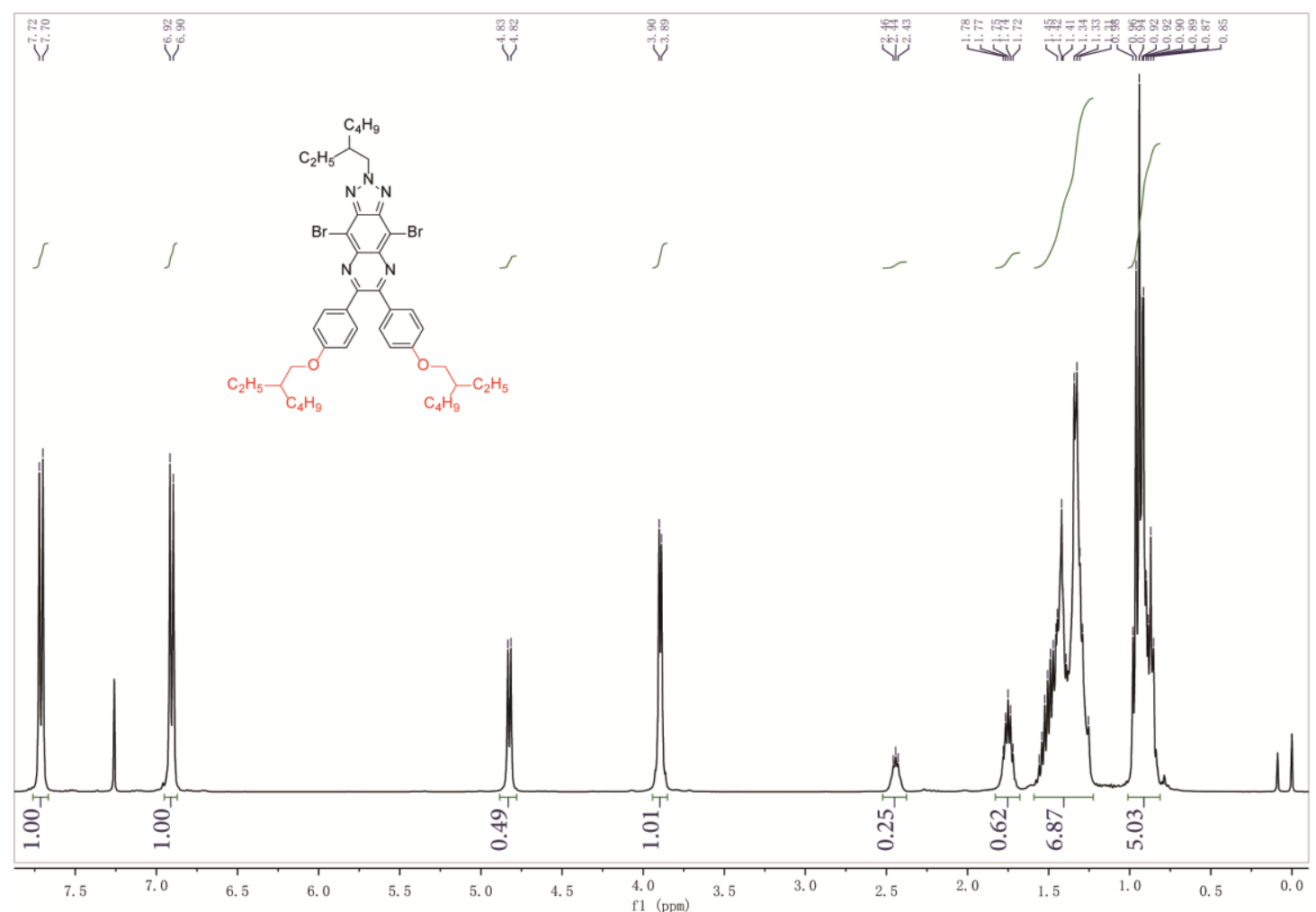

Fig. S6 ${ }^{1} \mathrm{H}$ NMR spectrum of

4,9-dibromo-2-(2-ethylhexyl)-6,7-bis(4-((2-ethylhexyl)oxy)phenyl)-2H-[1,2,3]triazolo[4,5-g]quin oxaline (M2) 


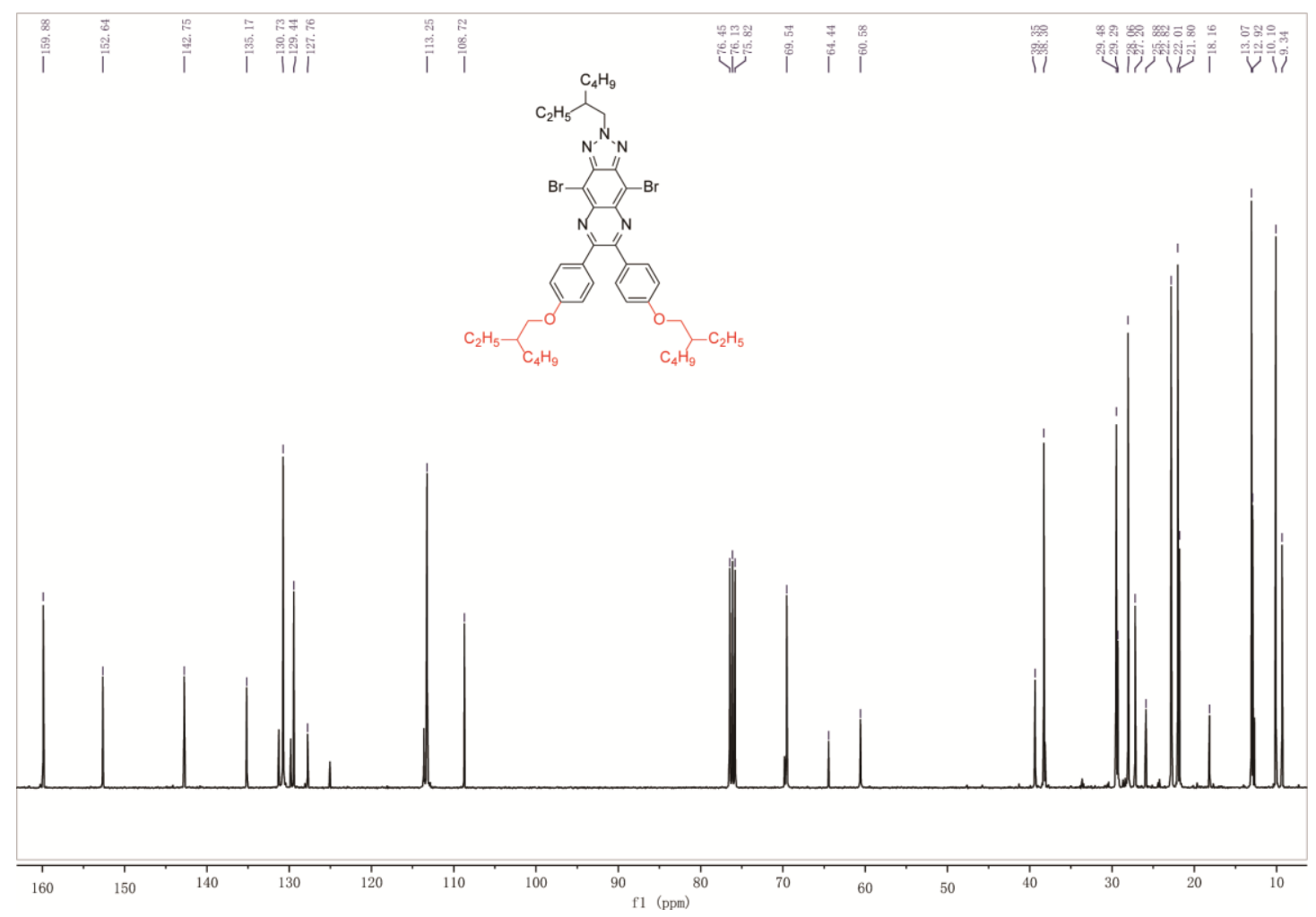

Fig. $\mathbf{S} 7{ }^{13} \mathrm{C}$ NMR spectrum of

4,9-dibromo-2-(2-ethylhexyl)-6,7-bis(4-((2-ethylhexyl)oxy)phenyl)-2H-[1,2,3]triazolo[4,5-g]quin oxaline (M2)

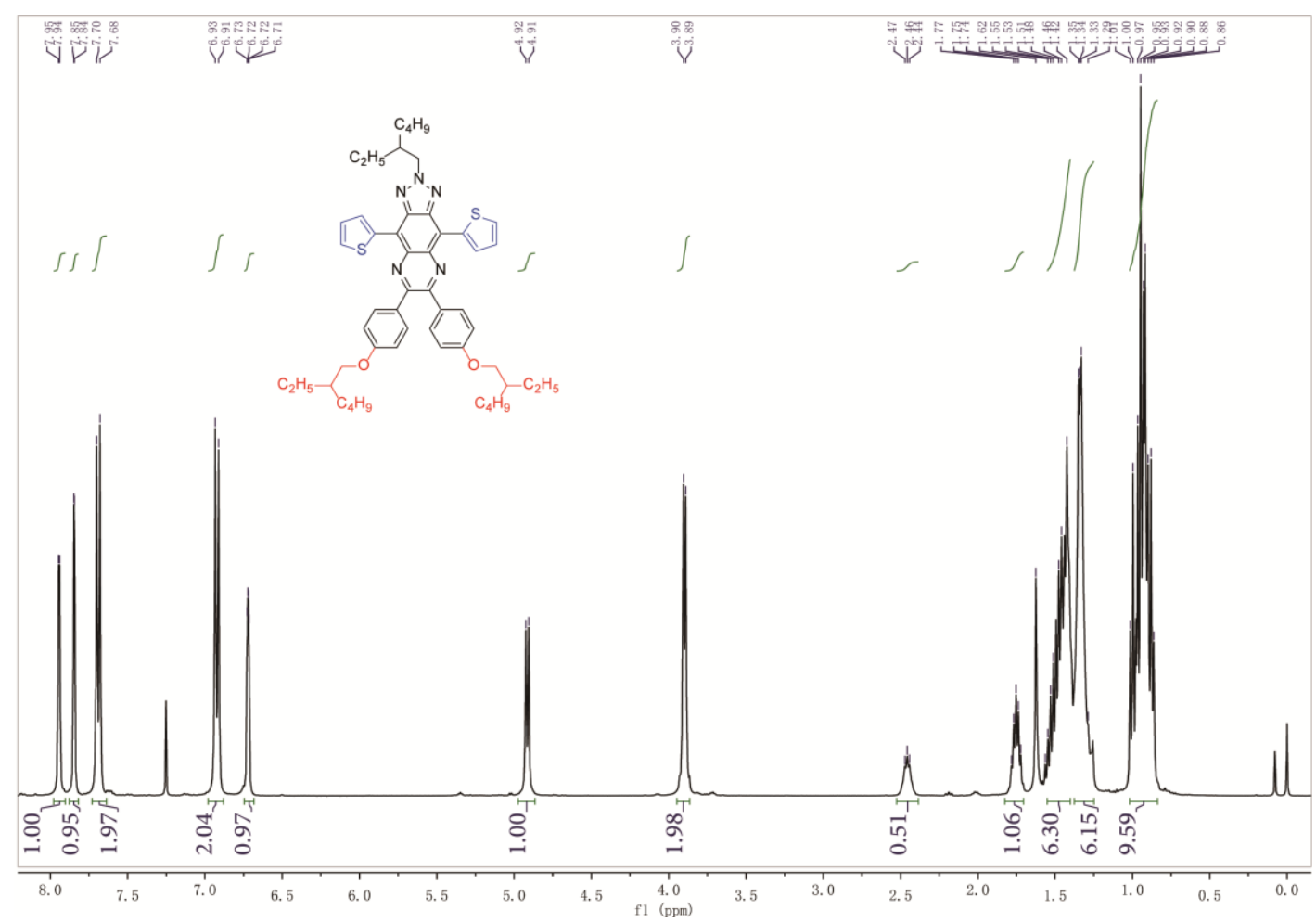

Fig. S8 ${ }^{1}$ H NMR spectrum of

2-(2-ethylhexyl)-6,7-bis(4-((2-ethylhexyl)oxy)phenyl)-4,9-di(thiophen-2-yl)-2H-[1,2,3]triazolo[4, 5 -g]quinoxaline (6) 


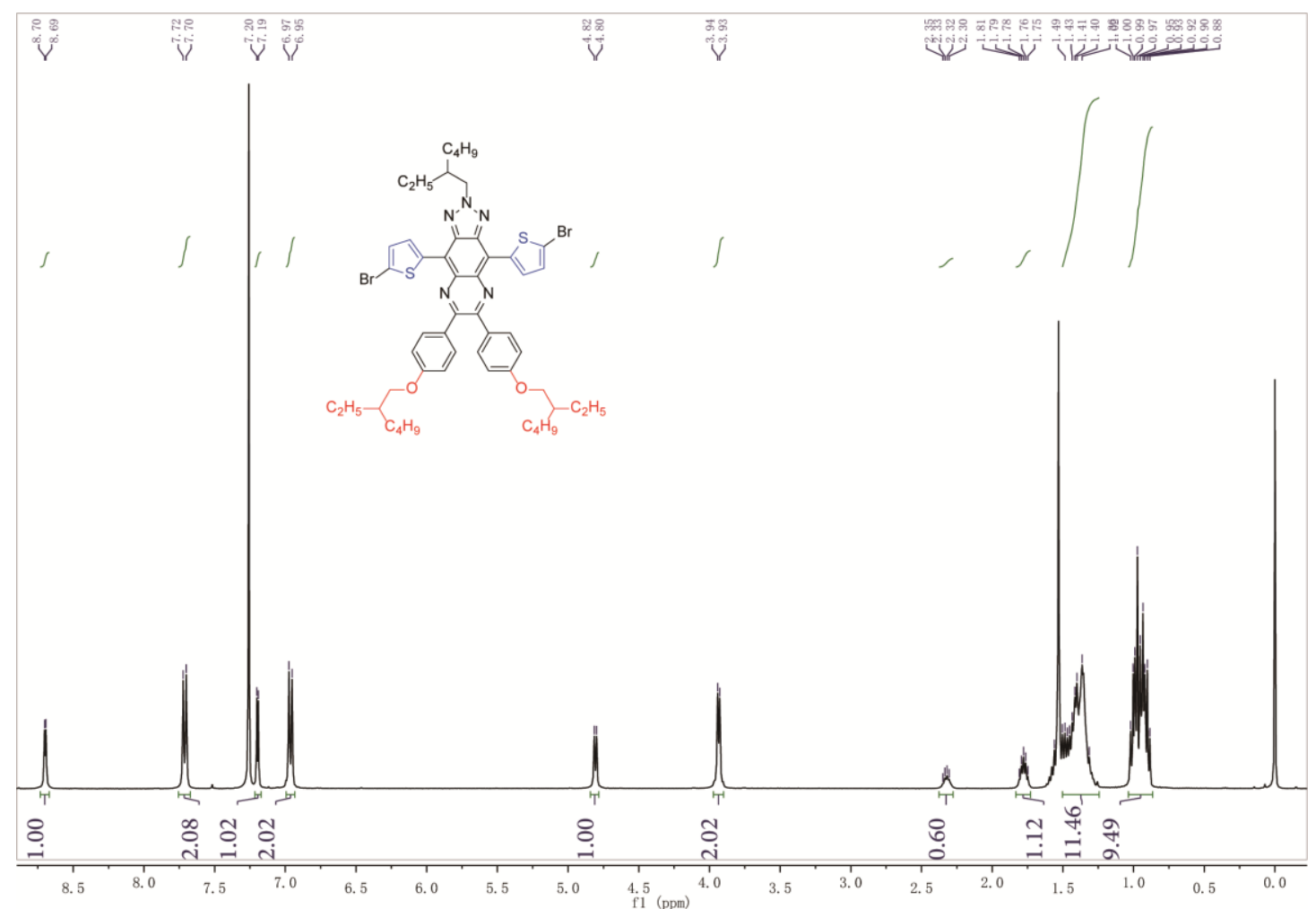

Fig. S9 ${ }^{1} \mathrm{H}$ NMR spectrum of

4,9-bis(5-bromothiophen-2-yl)-2-(2-ethylhexyl)-6,7-bis(4-((2-ethylhexyl)oxy)phenyl)-2H-[1,2,3]tr iazolo[4,5-g]quinoxaline (M3) 


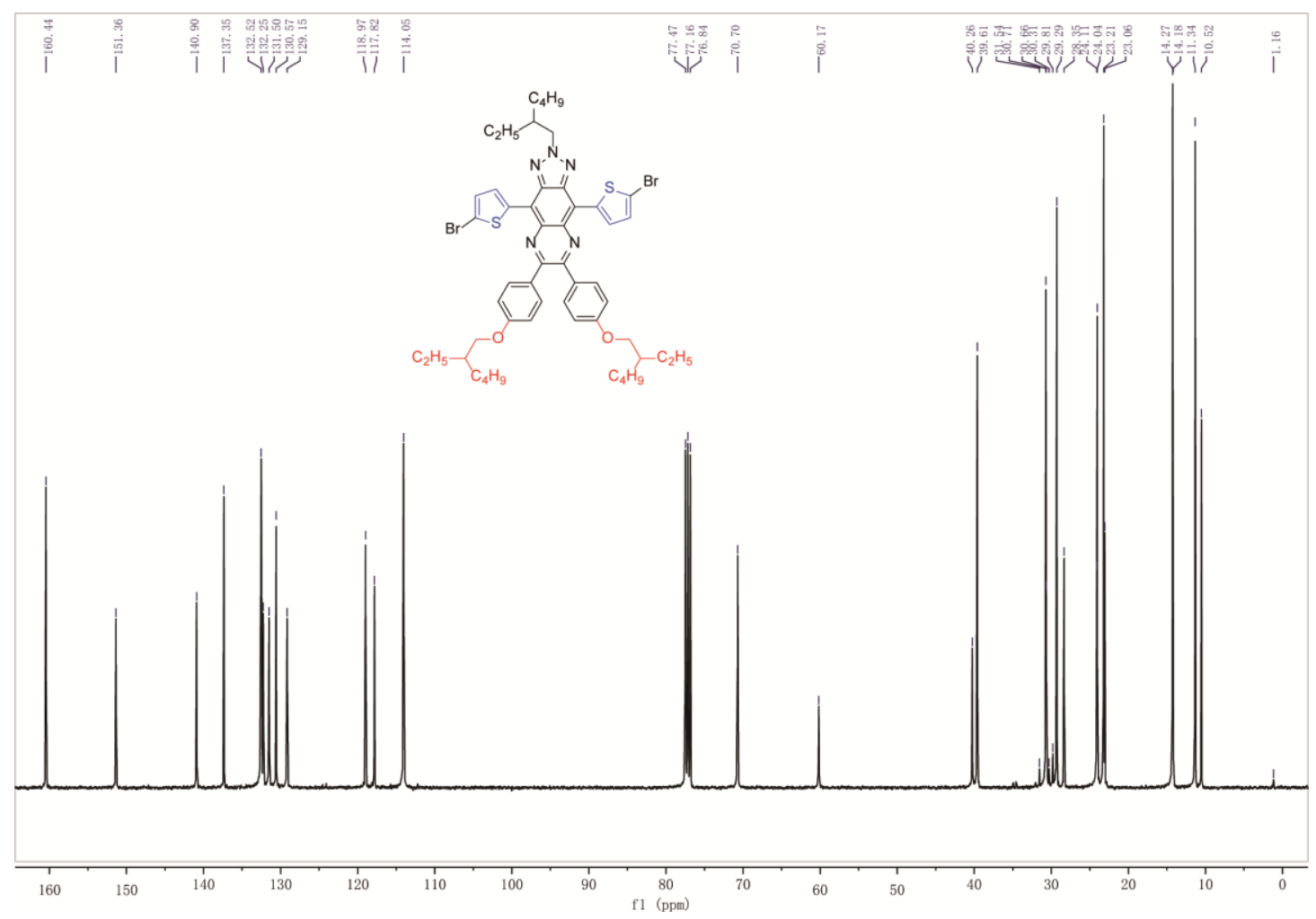

Fig. S10 ${ }^{13} \mathrm{C}$ NMR spectrum of

4,9-bis(5-bromothiophen-2-yl)-2-(2-ethylhexyl)-6,7-bis(4-((2-ethylhexyl)oxy)phenyl)-2H-[1,2,3]tr iazolo[4,5-g]quinoxaline (M3)

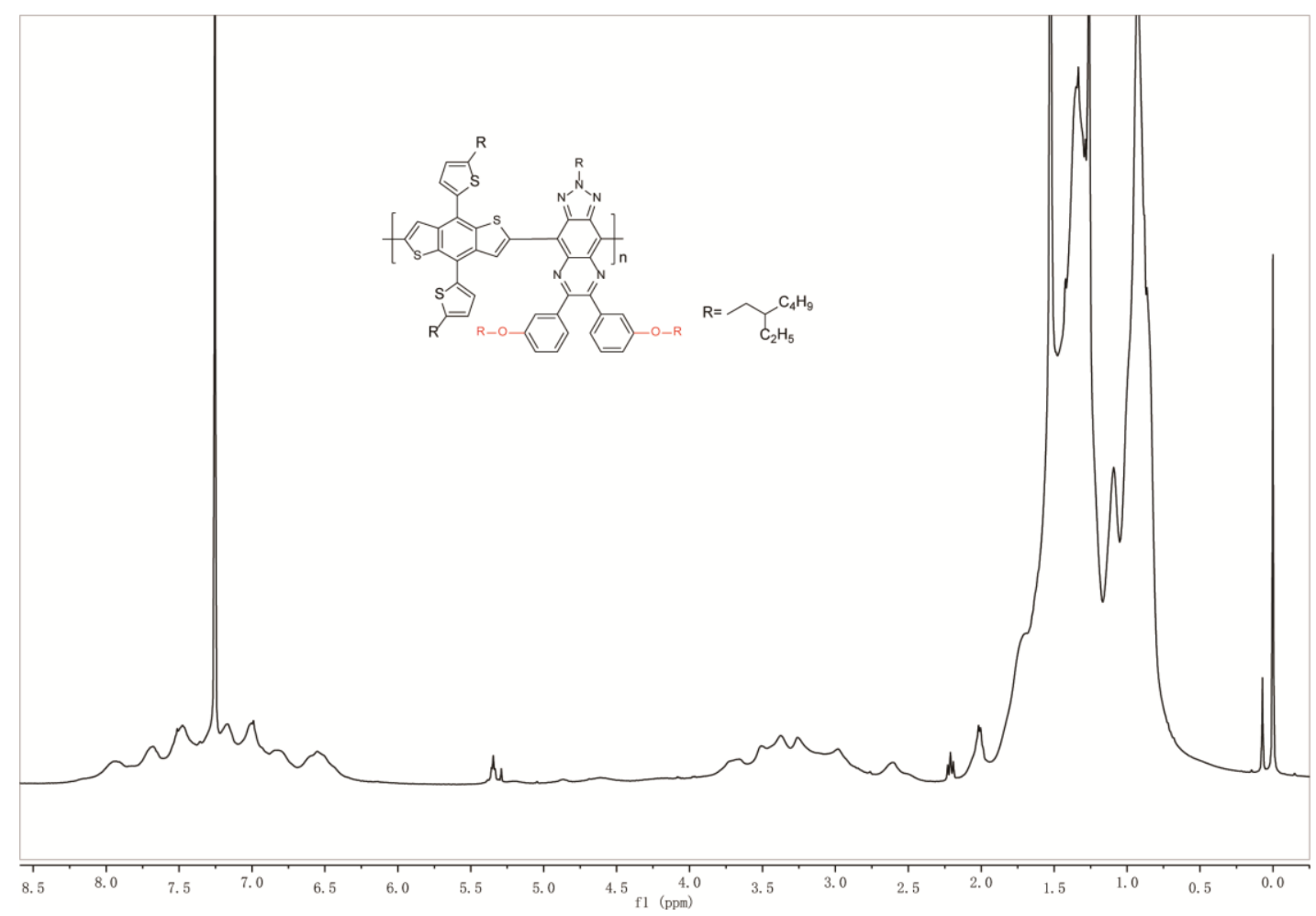

Fig. S11 ${ }^{1} \mathrm{H}$ NMR spectrum of

Poly([4,4,9,9-tetrakis(4-hexylphenyl)-4,9-dihydro-sindaceno[1,2-b:5,6-b']

dithiophene-2,7-diyl]-co-[6-(2-ethylhexyl)-[1,2,5]thiadiazolo[3,4-f]benzotriazole-4,8-diyl])

(P1) 


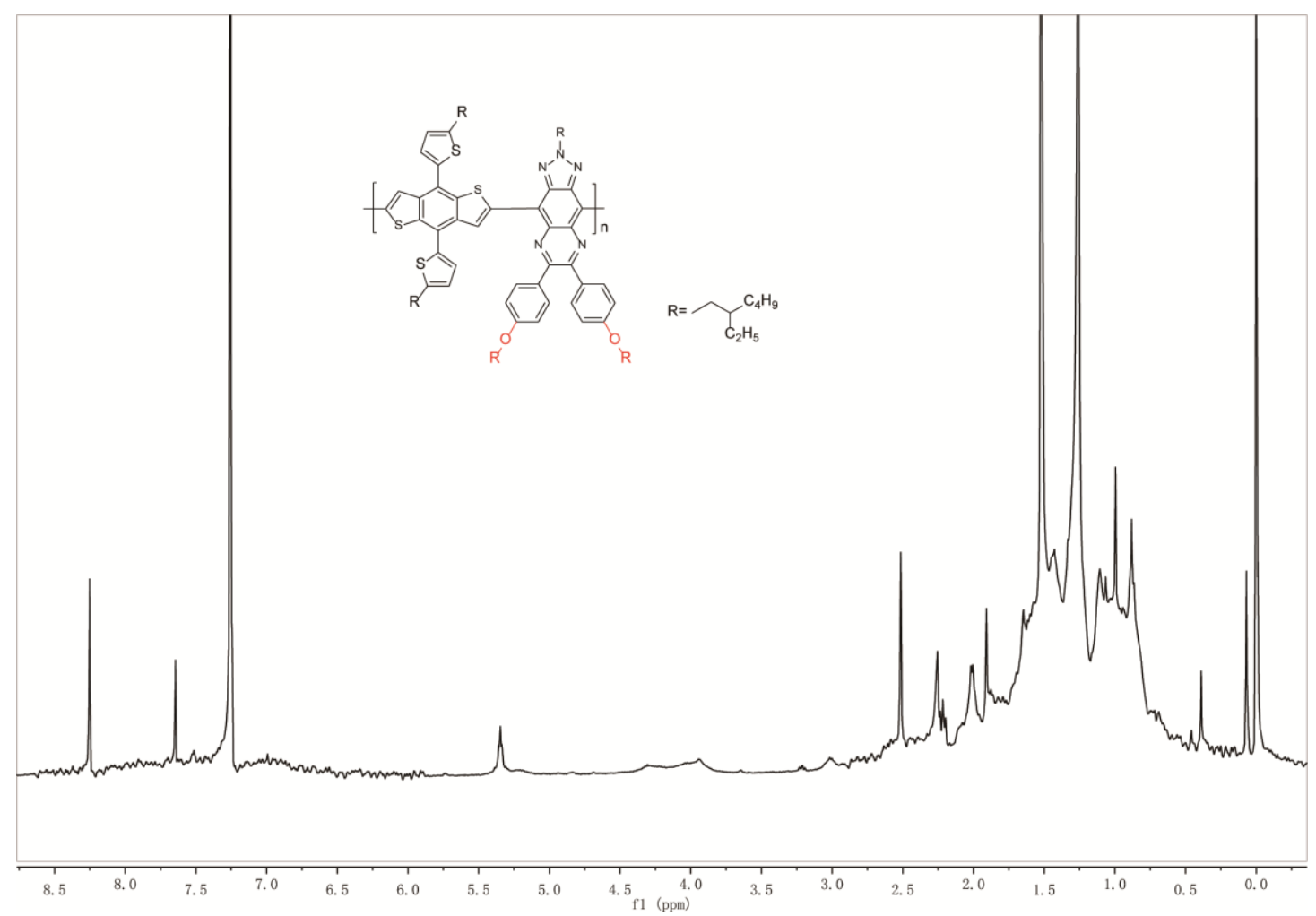

Fig. S12 ${ }^{1} \mathrm{H}$ NMR spectrum of

Poly([2,5-bis(2-decyltetradecyl)-2,5-dihydropyrrolo[3,4-c]pyrrole-1,4-dione-3,6-dithienyl]-co-[6-( 2-ethylhexyl)-[1,2,5]thiadiazolo[3,4-f]benzotriazole-4,8-diyl]) (P2)

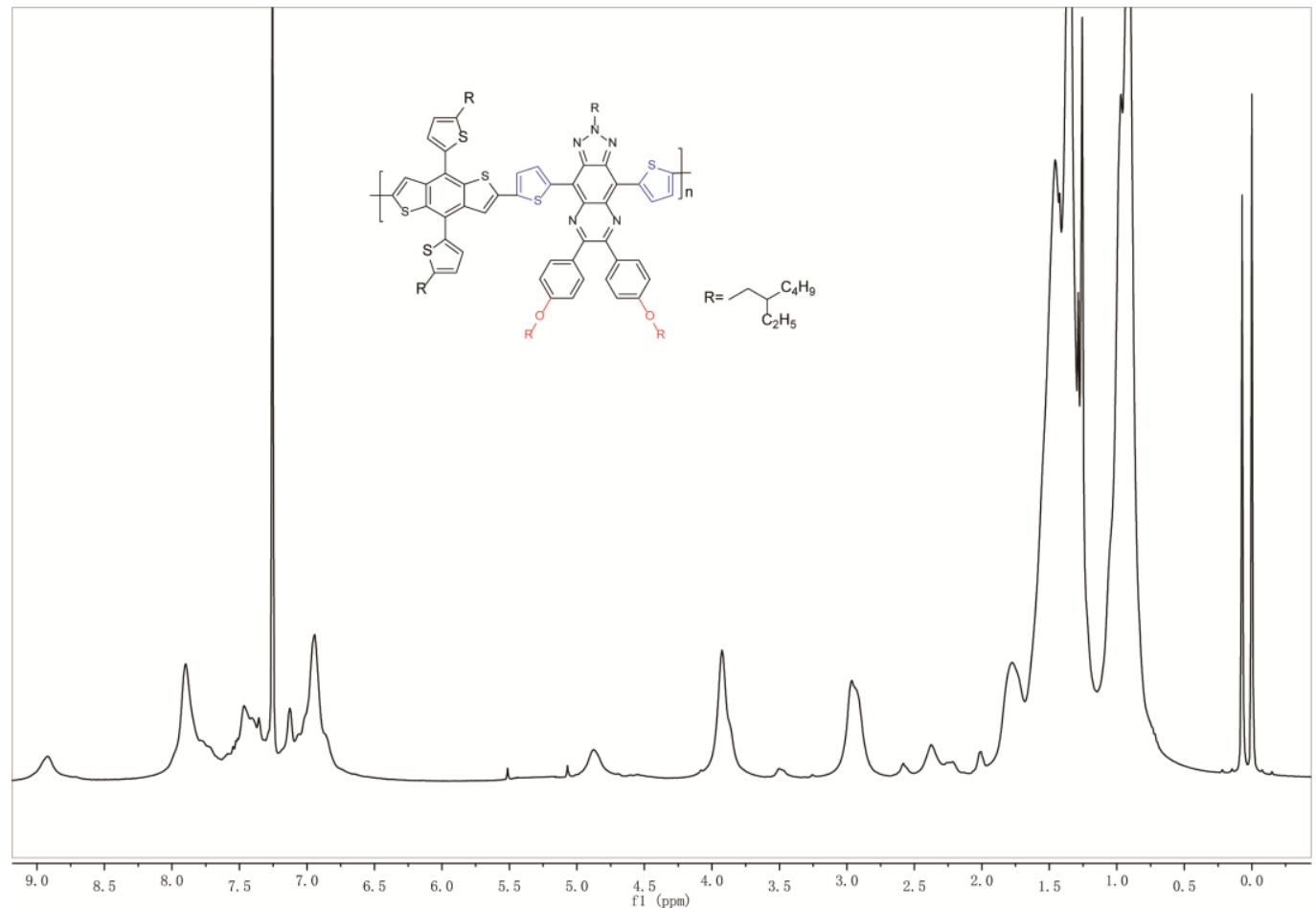

Fig. S13 ${ }^{1} \mathrm{H}$ NMR spectrum of

Poly([4,8-bis(5-(2-ethylhexyl)thiophen-2-yl)benzo[1,2-b:4,5-b']dithiophene-2,6-diyl] -co-[6-(2-ethylhexyl)-[1,2,5]thiadiazolo[3,4-f]benzotriazole-4,8-diyl]) (P3) 